\title{
Hovenia dulcis T. Fruit Colorimetry for Determination of Physiological Maturity of Seeds
}

\author{
Maria S. F. Vera Cruz ${ }^{1}$, Maria E. L. Rocha ${ }^{1}$, Ana C. P. Ristau ${ }^{1}$, Pablo W. R. Coutinho ${ }^{1}$, Marlene M. Malavasi ${ }^{1}$, \\ Ubirajara C. Malavasi ${ }^{1}$, Hannah Braz ${ }^{1}$, Danieli R. Klein ${ }^{1}$, Deise C. Vitto ${ }^{1} \&$ Néri Ebeling ${ }^{1}$ \\ ${ }^{1}$ Department of Plant Production, State University of the West of Paraná, Marechal Cândido Rondon, PR, Brazil \\ Correspondence: Maria S. F. Vera Cruz, Department of Plant Production, State University of the West of Paraná, \\ Rua Pernambuco, 1599, Marechal Cândido Rondon, PR, Brazil. Tel: 55-91-98862-1784. E-mail: \\ soraiaf12@hotmail.com
}

Received: October 22, 2017

Accepted: November 27, 2017

Online Published: December 15, 2017

doi:10.5539/jas.v10n1p293

URL: https://doi.org/10.5539/jas.v10n1p293

\begin{abstract}
Hovenia dulcis is a pioneering species, fast growing and considered exotic and invasive. The species has multiplicity of uses and reproduces by seeds. In this sense, it is extremely important to know the physiological maturity of $H$. dulcis seeds. The objective of the research was to determine if the maturation of $H$. dulcis seeds is achieved concomitantly with the physiological maturation of the false fruit. Seeds were obtained from seven adult trees located in Marechal Cândido Rondon, PR. The fruits were classified in five maturation stages, determined according to color chart. In order to verify the effects of the maturation stages of the false fruit on the physiological maturity seeds biometric characteristics, moisture content, germination, vigor and seedling development were evaluated. Seeds of $H$. dulcis presented evolution of maturation at the same time as the false fruit. For the evaluated parameters, seeds classified as stage 1 (7.5 YR 5/8) showed the best results for seed germination and seedling development, in contrast to those classified as stage 5 (2.5 YR 3/4), which presented low germination and delay in the development of seeds and seedlings.
\end{abstract}

Keywords: force, germination, exotic, maturation stage

\section{Introduction}

Hovenia dulcis, also known as Japan grape, belongs to the Rhamnaceae family. It is a pioneer species, fast growing, exotic and invasive (Schumacher, Brun, Illana, Dissiuta, \& Agne, 2008; Zenni \& Ziller, 2011). Flowering occurs in spring - summer and fruiting in winter (Backes \& Irggang, 2004).

In Brazil, this tree grows mainly in the south region. It presents intense natural regeneration due to the zoocoric dispersion. In addition, the species presents perspective for production of wood (Buono, Oliveira, \& Paiva, 2008; Schumacher et al., 2008). Despite this, japon grape has been found to compromise the dissemination and impair the development of some species, even replacing them due to aggressiveness and ease adaptation (Pimentel, Putton, Watzlawick, Valério, \& Saueressig, 2008).

Japan grape is a deciduous plant, being able to reach up to $25 \mathrm{~m}$ in height, with a wide crown. Its bark is smooth, lightly fissured, dark brown to dark gray in color (Pereira, Carvalho, \& Biasi, 2010). The fruit of the Japan grape consists of a small, globose dried capsule with 2 to 4 seeds, attached to a fleshy peduncle of cinnamon color, with a sweet and pleasant taste. The seeds of the plant are orange or reddish when freshly harvested and turning to brown and black over time. Formed by three locules, the fruit is the size of a pea, containing the seeds (Kim \& Han, 2008; Kamala-Kannan et al., 2011).

The peduncle, considered the false fruit, is rich in sucrose, the pulp having the same aroma as pear. It is also used by wildlife and to supplement the feeding of swine and birds (Lorenzi, Souza, Torres, \& Bacher, 2003; Bampi, Bicudo, Fontoura, \& Ribani, 2010; Rosa, Longhi, \& Ludwig, 2008). In addition, leaves of young plants may produce chemical compounds with antimicrobial properties (Buono et al., 2008).

The species presents multiplicity of uses and reproduces, mainly by seeds. Therefore it becomes important the knowledge of the germinative power (Pereira et al., 2010).

Seed maturation can be characterized as a process resulting from morphological, physiological and functional changes that occur from the fertilization of the ovules (Popinigis, 1985; Carvalho \& Nakagawa, 2000). 
The "physiological maturity point" is the one in which the seeds present the highest physiological quality, ie maximum dry mass, germination and vigor value (Popinigis, 1985).

In this sense, it is extremely important to know the physiological maturity of the seed, in order to determine the best stage for the harvest and germination, ensuring the greatest success in seed development and minimizing the losses caused by inadequate collection of the material to be propagated.

The objective of the research was to determine if the maturity of Hovenia dulcis seeds is achieved concomitantly with the physiological maturation of the false fruit.

\section{Material and Methods}

The experiment was carried out at the Seed Technology Laboratory of the State University of the West of Paraná (UNIOESTE), Campus de Marechal Cândido Rondon, using H. dulcis seeds.

Seeds were obtained from seven adult trees located in Marechal Cândido Rondon, PR (24 $32^{\prime} 42^{\prime \prime} \mathrm{S}$ and $54^{\circ} 02^{\prime} 35^{\prime \prime} \mathrm{W}$, altitude of $420 \mathrm{~m}$ ). Seeds were separated into five maturation stages, according to the color of the false fruit according to a Munsell color charts for plant tissues model (Munsell, 1976). Maturation stages were: 7.5 YR 5/8 (stage 1); 7.5 YR 5/6 (stage 2); 2.5 YR 4/6 (stage 3); 7.5 YR 4/4 (stage 4) and 2.5 YR 3/4 (stage 5), visualized in Table 1.

Table 1. Coloring of $H$. dulcis false fruit at different maturation stages.

\begin{tabular}{|c|c|c|}
\hline Stage of maturation & Coloring the false fruit & Letter from Munsell \\
\hline 1 & & $7.5 \mathrm{YR} 5 / 8$ \\
\hline 2 & & $7.5 \mathrm{YR} 5 / 6$ \\
\hline 3 & & $2.5 \mathrm{YR} 4 / 6$ \\
\hline 4 & & $7.5 \mathrm{YR} 4 / 4$ \\
\hline 5 & & $2.5 \mathrm{YR} 3 / 4$ \\
\hline
\end{tabular}


The seeds were manually extracted and the biometric parameters length and diameter using a digital caliper were subsequently measured. The water content was determined by the oven method at $105 \pm 3{ }^{\circ} \mathrm{C}$, during 24 hours (Ministério da Agricultura Pecuária e Abastecimento [MAPA], 2009), with 5 treatments, 4 replicates of 25 seeds each. The mass of one thousand seeds was calculated according to the RAS Seed Analysis Rule (MAPA, 2009).

\subsection{Germination Test}

The seeds were germinated using germitest paper, moistened with distilled water 2.5 times the value of their weight and packed in a germination chamber type BOD, with constant temperature of $25^{\circ} \mathrm{C}$ and photoperiod of 12 hours. During the germination test, daily tally of normal and abnormal seedlings were performed, with criteria determined by the Rules for Seed Analysis (RSA) (MAPA, 2009). Based on the data, the percentage of germination, the average germination speed (AGS) and the mean germination time (MGT) were calculated. The calculation of the percentage of germination of AGS and MGT were performed according to Labouriau (1983):

$$
G(\%)=(N / A) \times 100
$$

Where, $G$ is the percentage of germination; $N$ is the number of germinated seeds (during 40 days); and $A$ is the total number of seeds placed to germinate.

$$
\begin{gathered}
M G T(\text { days })=\left(\sum n t \times t i\right) /\left(\sum n t o t a l\right) \\
A G S\left(\text { days }^{-1}\right)=1 / t
\end{gathered}
$$

Where, $M G T$ refers to the mean germination time in days; $n t$ is the number of seeds germinated in a time interval; $t i$ is the time interval (40 days); ntotal is the total number of seeds germinated; $v$ is the average speed of germination.

\subsection{Stamina Tests}

\subsubsection{Germination Speed Index}

The germination test was performed together with the number of seeds germinated daily, obtaining the germination index from the formula presented by Maguire (1962):

$$
G S I=(G 1 / N 1+G 2 / N 2+G \mathrm{n} / N \mathrm{n})
$$

Where, $G S I=$ germination velocity index; $G=$ number of seeds germinated; $N=$ number of days of sowing.

\subsubsection{Emergency Velocity Index}

It was conducted in a greenhouse, where the seeds were sown in trays containing commercial substrate, and the number of emerged seedlings with above ground tisues was recorded daily until emergency stabilization, and this was calculated by the formula proposed by Maguire (1962):

$$
E S I=(E 1 / N 1+E 2 / N 2+E \mathrm{n} / N \mathrm{n})
$$

Where, $E S I=$ emergency speed index. $E 1, E 2, E \mathrm{n}=$ number of normal seedlings computed in the first count, the second count and the last count. $N 1, N 2, N \mathrm{n}=$ number of days of sowing at the first, second and last count.

\subsubsection{Accelerated Aging}

The seeds were placed in gerbox boxes with a mesh, containing $40 \mathrm{~mL}$ of water to guarantee a relative humidity of about $100 \%$. The seeds were arranged in a uniform layer on the surface of the inner screen and then placed in the chamber regulated to constant temperature of $42{ }^{\circ} \mathrm{C}$ for 72 hours for aging adapting the methodology performed by Pereira et al. (2010).

\subsubsection{Vigor Test Based on Seedling Performance}

At the end of the germination test, the seed vigor characteristics based on the development of the seedling were evaluated, namely hypocotyl base diameter (HD), radicle length (RL), hypocotyl length (HL), leaflets number (LN), mass of hypocotyl dry matter (MHDM) and mass of root dry matter (MRDM).

\subsection{Statistical Analysis}

The experimental design was completely randomized, with 5 maturation stages, 4 replicates of 25 seeds each. The results were tested for normality and homogeneity and submitted to analysis of variance ( $\mathrm{F}$ test). When appropriated, means were compared by Tukey test at $1 \%$ of probability. 


\section{Results and Discussion}

\subsection{Seed Characterization}

There was a significant difference between the treatments (Table 2) for morphometric characteristics of seeds, moisture content, weight of one thousand seeds and seed diameter.

Table 2. Biometric characterization of $H$. dulcis seeds at different stages of the false fruit maturation

\begin{tabular}{llll}
\hline Stage of maturation & MC $(\%)$ & TSW $(\mathrm{g})$ & SD $(\mathrm{mm})$ \\
\hline 7.5 YR 5/8 & $10.89 \mathrm{a}$ & $2.045 \mathrm{ab}$ & $3.52 \mathrm{c}$ \\
7.5 YR 5/6 & $11.53 \mathrm{a}$ & $2.099 \mathrm{a}$ & $3.93 \mathrm{a}$ \\
$2.5 \mathrm{YR} 4 / 6$ & $10.09 \mathrm{~b}$ & $1.943 \mathrm{c}$ & $3.84 \mathrm{ab}$ \\
7.5 YR 4/4 & $10.95 \mathrm{a}$ & $2.018 \mathrm{~b}$ & $3.65 \mathrm{bc}$ \\
2.5 YR 3/4 & $9.36 \mathrm{~b}$ & $2.049 \mathrm{ab}$ & $3.88 \mathrm{a}$ \\
\hline CV $(\%)$ & 3.41 & 2.41 & 2.48 \\
\hline
\end{tabular}

Note. $\mathrm{MC}=$ Moisture content, $\mathrm{TSW}=$ thousand seed weight $(\mathrm{TSW}), \mathrm{SD}=$ seed diameter $(\mathrm{SD}) .{ }^{*}$ Means followed by the same letter in the columns do not differ by Tukey test $(\mathrm{p} \leq 0.01)$.

Table 2 shows that the moisture content for the maturation stages 7.5 YR 5/8, 5/6 and 4/4 did not differ statistically and presented higher values than the maturation stages 2.5 YR $4 / 6$ and 3/4. This result can be justified because the lower moisture values coincide with the stages of lower maturation of the false fruit, and it was inferred that the seeds lost moisture as the maturation progressed. The lowest value for DMM was observed in the 2.5 YR 4/6 stage and the highest value in the 7.5 YR 5/6 stage, however this did not differ statistically from the 7.5 YR 5/8 and 2.5 YR 3/4. The seeds of the 2.5 YR 4/6 stage presented lower values of FSM, with averages varying from 0.37 to $0.41 \mathrm{~g}$, for the other treatments there was no significant difference. The length of the seed was not influenced by the maturation stage, with a mean of $4.32 \mathrm{~mm}$.

The largest diameters were measure in seeds of stages 7.5 YR 5/6, 2.5 YR 4/6 and 2.5 YR 3/4, which did not differ from each other. In reports from Rodo, Perleberg, Torres, Gentil, and Tessaroli Neto (2001), and Gaspar and Nakagawa (2002) seed size is one of the factors that can influence seedling germination and vigor.

Seeds of the 2.5 YR 3/4 stage had higher dry biomass with average of $0.373 \mathrm{~g}$, coinciding with the stage where the seeds presented lower water content. At this stage the fruits had already matured. However did not differ statistically from the stages 7.5 YR $5 / 8,5 / 6$ and $4 / 4$.

Marcos-Filho (2015) explained that the seeds present four phases of post-fertilization development. Phase I and II present slow growth and low increase in dry biomass and high water content, in phase III the seeds reach the maximum dry biomass and in phase IV seeds lose water with greater intensity, without significant modification of the dry biomass.

For $H$. dulcis seeds, although significant differences were found between the treatments, it was verified that all presented low values of water content, ranging from 9.36 to $10.95 \%$, as well as little variation in dry biomass. The probable justification for these results would be that the seeds collected at all stages of maturation had already reached phase IV or were in transition from phase III to phase IV.

\subsection{Germination Test}

Differences ( $\mathrm{p} \leq 0.01$ ) were detected for germination percentage and germination speed index as a function of seed maturation stage. On the other hand, no significant effect could be inferred with data from mean germination time and average germination speed (Table 3 ). 
Table 3. Germination parameters of $H$. dulcis seeds at different stages of false fruit maturation

\begin{tabular}{lllll}
\hline Maturation stages & G $(\%)$ & GSI & MGT (days) & ${\text { AGS }\left(\text { days }^{-1}\right)}$ \\
\hline 7.5 YR 5/8 & $72.50 \mathrm{a}$ & $0.58 \mathrm{a}$ & $28.263 \mathrm{a}$ & $0.035 \mathrm{a}$ \\
7.5 YR 5/6 & $41.25 \mathrm{~b}$ & $0.47 \mathrm{ab}$ & $31.496 \mathrm{a}$ & $0.032 \mathrm{a}$ \\
2.5 YR 4/6 & $31.25 \mathrm{~b}$ & $0.31 \mathrm{bc}$ & $28.130 \mathrm{a}$ & $0.036 \mathrm{a}$ \\
$7.5 \mathrm{YR} \mathrm{4/4}$ & $41.25 \mathrm{~b}$ & $0.34 \mathrm{bc}$ & $27.037 \mathrm{a}$ & $0.037 \mathrm{a}$ \\
2.5 YR 3/4 & $25.00 \mathrm{~b}$ & $0.19 \mathrm{c}$ & $27.516 \mathrm{a}$ & $0.037 \mathrm{a}$ \\
\hline CV $(\%)$ & 21.26 & 22.38 & 10.37 & 11.81 \\
\hline
\end{tabular}

Note. $\mathrm{G} \%=$ Percentage of germination, $\mathrm{GSI}=$ germination speed index, $\mathrm{MGT}=$ mean germination time, $\mathrm{AGS}=$ average germination speed. * Means followed by the same letter in the columns do not differ by Tukey test ( $\mathrm{p} \leq$ $0.01)$.

Seeds of the 7.5 YR 5/8 stage showed the highest percentage of germination (Table 3). There was a drastic reduction in percentage of germination compared to the less advanced stage of false fruit maturation classified according to the Munsell color chart as 7.5 YR 5/8. These results indicated that there is a reduction in the physiological potential of $H$. dulcis seed as maturation of the false fruit progresses.

Published studies with several species showed germination differences in relation to fruit maturation such as with Jatropha curcas L. (Dranski et al., 2010), Eugenia pyriformis Cambess and Eugenia involucrata DC. (Oro et al., 2012).

A similar trend was detected with germination speed index where the highest averages resulted forseed from fruits of stages 7.5 YR 5/8 and 7.5 YR 5/6, concomitantly to reductions in the rate of germination for the other maturation stages.

The mean germination time and the mean germination speed were not influenced by fruit maturation stage. The average obtained in MTG ranged from 27.037 to 31.496 days and AGS from 0.035 to 0.037 seeds per day.

\subsection{Index of Emergency Speed}

Regarding the emergence percentage, a significant difference $(\mathrm{P}<0.05)$ was calculated among maturation stages in H. dulcis seeds (Table 4).

Table 4. Emergency Velocity Index (EVI) in H. dulcis seeds at different stages of false fruit maturation

\begin{tabular}{ll}
\hline Maturation stages & ESI \\
\hline 7.5 YR 5/8 & $0.227 \mathrm{a}$ \\
7.5 YR 5/6 & $0.090 \mathrm{bc}$ \\
2.5 YR 4/6 & $0.113 \mathrm{abc}$ \\
7.5 YR 4/4 & $0.184 \mathrm{ab}$ \\
2.5 YR 3/4 & $0.069 \mathrm{c}$ \\
CV $(\%)$ & 2.45 \\
\hline
\end{tabular}

Note. ${ }^{*}$ Means followed by the same letter in the columns do not differ by Tukey test $(\mathrm{p} \leq 0.01)$.

The results showed a higher emergence speed for the seeds at the fruit maturation stage 1 ( 7.5 YR 5/8). This resulted due the start of the maturation process and consequently the seeds were more suitable for development.

The lowest emergence speed was obtained with seed from fruits at the final stage of maturation subjected to deterioration with an average of 0.069 . That result did not differ statistically from maturity stage 2 (7.5 YR 5/6) and 3 (2.5 YR 4/6). Similar results were found by Costa, Bruno, Souza, and Lima (2001) with maturation stages of Spondias tuberosa Arr. Câm. (39.61\%) followed by advanced (37.41\%) and green (35.32\%) maturation.

However, it should be noted that the emergence rate for all stages of false fruit ripening evaluated in this study was considered low, one of the justifications is related to seed conditions and climatic conditions, because under greenhouse conditions the seeds presented a delay in emergence of approximately 25 days, seeds in the germination chamber started the process with approximately 10 days. Another justification can be considered when it comes to the seed coat, because in some environmental conditions, Japan grape seed may have variable 
permeability which difficult germination. Zanon and Carpanezzi (1993) suggested that tegument of Japan grape seeds has impermeability.

\subsection{Accelerated Aging}

Seed aging for 72 hours at $42{ }^{\circ} \mathrm{C}$ accelerated the germination process, improving the physiological potential. For the germination parameter, there was a significant difference between fruit maturation stages. The highest germination stage was achieved with seeds from 7.5 YR 5/8 stage, with a mean of $78.75 \%$ demonstrating that seed harvesting should be performed when fruits are at that stage to maximizing germination and minimizing seed losses (Table 5).

Table 5. Average accelerated aging values, for 72 hours, of $H$. dulcis seeds at different stages of false fruit maturation

\begin{tabular}{lllll}
\hline Maturation stages & G $(\%)$ & GSI & MTG (days) & ${\text { ASG }\left(\text { days }^{-1}\right)}^{-1}$ \\
\hline 7.5 YR 5/8 & $78.75 \mathrm{a}$ & $0.66 \mathrm{a}$ & $25.19 \mathrm{a}$ & $0.040 \mathrm{a}$ \\
7.5 YR 5/6 & $62.50 \mathrm{ab}$ & $0.51 \mathrm{a}$ & $26.16 \mathrm{a}$ & $0.038 \mathrm{a}$ \\
2.5 YR 4/6 & $52.50 \mathrm{ab}$ & $0.44 \mathrm{ab}$ & $26.88 \mathrm{a}$ & $0.038 \mathrm{a}$ \\
7.5 YR 4/4 & $53.75 \mathrm{ab}$ & $0.45 \mathrm{ab}$ & $25.65 \mathrm{a}$ & $0.040 \mathrm{a}$ \\
2.5 YR 3/4 & $35.00 \mathrm{~b}$ & $0.25 \mathrm{~b}$ & $29.96 \mathrm{a}$ & $0.034 \mathrm{a}$ \\
\hline CV $(\%)$ & 22.56 & 25.02 & 11.19 & 11.30
\end{tabular}

Note. $\mathrm{G}=$ Germination, $\mathrm{GSI}=$ Germination Speed Index, $\mathrm{MTG}=$ Mean Time of Germination, $\mathrm{ASG}=$ Average Speed of Germination. * Means followed by the same letter in the columns do not differ by Tukey test ( $\mathrm{p} \leq$ $0.01)$.

The lowest germination (35\%) was obtained with seeds from fruits of 2.5 YR 3/4 stage. False fruits at this color stage showed deterioration signs. For the other stages of maturation, the germination did not exceed $65 \%$.

Pereira et al. (2010) described an increase in the percentage of germination from 70 to $91 \%$ after 120 hours of treatment with Japan grape seeds.

Accelerated aging test can cause seed high respiration rate, reserve consumption and acceleration of metabolic processes leading to reduced quality, deterioration and death. However, results of germination with aged seeds can show higher mean values when compared to the germination of non-aged seeds (Piña-Rodrigues, Figliolia, \& Peixoto, 2004; Pontes, Corte, Borges, Silva, \& Borges, 2006).

For GSI, the highest mean obtained was for the 7.5 YR $5 / 8$ stage with 0.66 , but did not differ statistically from the 7.5 YR 4/4 stages; 7.5 YR 5/6 and 2.5 YR 4/6 (Table 5). The lowest value was found for the treatment 2.5 YR 3/4 with a mean of 0.25 , which did not differ statistically from the 2.5 YR $4 / 6$ and 7.5 YR $4 / 4$ stages. This result is related to the maturity of the seeds, when younger, the germination began more quickly.

After the dormancy is overcome, seeds of $H$. dulcis tend to present faster germination as a strategy that permits the rapid exploration of favorable conditions for germination (Schumacher et al., 2008). It was observed in a study developed by Pereira et al. (2010) under aging conditions for the same species, a reduction of MTG and elevation of ASG with 24 hours aging treatment.

For MTG there was no significant difference between the treatments. The means obtained were $25.65,26.16$, $25.19,26.88$, and 29.96 days for seeds from fruits classified at stage 7.5 YR 4/4, 7.5 YR 5/6, 7.5 YR 5/8, 2.5 YR $4 / 6$, and 2.5 YR 3/4, respectively.

In a study conducted by Moraes, Lopes, Farias, and Maciel (2016), the effect of the aging time was significant only at the temperature of $45^{\circ} \mathrm{C}$ for germination and GSI and at the temperatures of 41 and $45^{\circ} \mathrm{C}$ for MTG with the conventional method. The same authors stated that the saline aging method effect was significant only for GSI, at the three temperatures in Tabernaemontana fuchsiaefolia A. DC.

The average germination speed can identify the seed storage capacity and time. In this case, independent of the maturation stage, the seeds did not present a significant difference for the parameter. For ASG, the mean varied from 0.034 to 0.040 days $^{-1}$.

\subsection{Seedling Performance}

For the seedlings the parameters hypocotyl diameter, radicle length and number of leaflets were not influenced by the maturation stage of the seeds (Table 6). Regarding hypocotyl length, the best treatment was with seed 
from fruits classified as 7.5 YR 5/8. Although the 7.5 YR 5/6 treatment showed the lowest performance in the length of the hypocotyl, its dry biomass was the same as the treatment with the highest mean.

Table 6. Seedling development of $H$. dulcis at different stages of false fruit maturation

\begin{tabular}{lllllll}
\hline Maturation stages & HD $(\mathrm{mm})$ & RL $(\mathrm{cm})$ & HL $(\mathrm{cm})$ & LF & MHDB $(\mathrm{g})$ & MRDB $(\mathrm{g})$ \\
\hline 7.5 YR 5/8 & $0.59 \mathrm{a}$ & $2.80 \mathrm{a}$ & $3.43 \mathrm{a}$ & $2.82 \mathrm{a}$ & $0.069 \mathrm{a}$ & $0.026 \mathrm{a}$ \\
$7.5 \mathrm{YR} \mathrm{5/6}$ & $0.72 \mathrm{a}$ & $2.94 \mathrm{a}$ & $2.54 \mathrm{c}$ & $2.27 \mathrm{a}$ & $0.069 \mathrm{a}$ & $0.018 \mathrm{ab}$ \\
$2.5 \mathrm{YR} \mathrm{4/6}$ & $0.59 \mathrm{a}$ & $3.27 \mathrm{a}$ & $3.17 \mathrm{ab}$ & $3.13 \mathrm{a}$ & $0.031 \mathrm{~b}$ & $0.009 \mathrm{bc}$ \\
$7.5 \mathrm{YR} \mathrm{4/4}$ & $0.60 \mathrm{a}$ & $3.09 \mathrm{a}$ & $2.99 \mathrm{abc}$ & $3.16 \mathrm{a}$ & $0.046 \mathrm{~b}$ & $0.010 \mathrm{bc}$ \\
$2.5 \mathrm{YR} \mathrm{3/4}$ & $0.65 \mathrm{a}$ & $4.63 \mathrm{a}$ & $2.64 \mathrm{bc}$ & $2.88 \mathrm{a}$ & $0.026 \mathrm{~b}$ & $0.008 \mathrm{c}$ \\
\hline CV $(\%)$ & 11.11 & 32.68 & 9.27 & 17.13 & 19.99 & 27.29 \\
\hline
\end{tabular}

Note. $\mathrm{HD}=$ hypocotyl diameter, $\mathrm{RL}=$ radicle length, $\mathrm{HL}=$ hypocotyl length, $\mathrm{LN}=$ leaflets number, $\mathrm{MHDB}=$ mass of hypocotyl dry biomass, MRDB = mass of root dry biomass. * Means followed by the same letter in the columns do not differ by Tukey test $(\mathrm{p} \leq 0.01)$.

Similar behavior was observed by Lima et al. (2012) who verified that the maximum dry biomass and seedling length of Poincianella pyramidalis [(Tul.) L. P. Queiroz] coincided with the moment that the seeds also had the highest germination speed index.

Martins, Martinelli-Seneme, and Nakagawa (2008) found similar results working with Tabebuia chrysotricha (Mart. Ex DC.) Standl, where a higher shoot ratio was obtained in seedlings in fruits harvested at the initial maturation stage.

When evaluating the MHDB values, it was verified that seedlings produced from seed of fruits classied as $7.5 \mathrm{YR}$ $5 / 6$ and 7.5 YR 5/8 were larger compared to the other stages of maturation. In relation to the MRDB, it was verified that the initial maturation stage (7.5 YR 5/8) presented a higher dry mass, but did not differ from the 7.5 YR 5/6 stage. Thus, it is possible to observe that the two maturation stages had a higher dry mass for both shoot and radicle (Table 6).

Pessoa, Mann, Santos, and Ribeiro (2012) working with Jatropha curcas seeds found opposite results on dry biomass.

\section{Conclusion}

Seed development of Hovenia dulcis presented a parallel trend with maturation of its false fruit. For the evaluated parameters, seeds from fruits classified in stage 1 (7.5 YR 5/8) presented the best results for germination and development of seedlings. On the other hand, seeds from fruits classified in stage 5 (2.5 YR 3/4) presented low germination and delay in the development of seedlings.

\section{References}

Backes, P., \& Irgang, B. (2004). Árvores cultivadas no sul do Brasil: Guia de Identificação e interesse paisagístico das principais espécies exóticas. Porto Alegre, RS: Editora Paisagens do Sul.

Bampi, M., Bicudo, M. O. P., Fontoura, P. S. G., \& Ribani, R. H. (2010). Composição centesimal do fruto, extrato concentrado e da farinha da uva-do-japão. Ciência Rural, 40(11), 2361-2367. https://doi.org/ $10.1590 / \mathrm{S} 0103-84782010001100018$

Buono, R. A., Oliveira, A. B., \& Paiva, E. A. S. (2008). Anatomy, ultrastructure and chemical composition of food bodies of Hovenia dulcis (Rhamnaceae). Annals of Botany, 101(9), 1341-1349. https://doi.org/10.1093/ $\mathrm{aob} / \mathrm{men} 052$

Carvalho, N. M., \& Nakagawa, J. (2000). Sementes: Ciência, tecnologia e produção. Jaboticabal, SP: FUNEP.

Costa, N. P., Bruno, R. D. A., Souza, F. X., \& Lima, E. D. P. A. (2001). Efeito do estádio de maturação do fruto e do tempo de pré-embebição de endocarpos na germinação de sementes de umbuzeiro (Spondias tuberosa Arr. Câm.). Revista Brasileira de Fruticultura, 23(3), 738-741. https://doi.org/10.1590/S0100-294520010 00300060

Dranski, J. A. L., Pinto Júnior, A. S., Steiner, F., Zoz, T., Malavasi, U. C., Malavasi, M. M., \& Guimarães, V. F. (2010). Physiological maturity of seeds and colorimetry of fruits of Jatropha curcas L. Revista Brasileira de Sementes, 32(4), 158-165. https://doi.org/10.1590/S0101-31222010000400018 
Gaspar, C. M., \& Nakagawa, J. (2002). Influência do tamanho na germinação e no vigor de sementes de milheto (Pennisetum americanum (L.) Leeke). Revista Brasileira de Sementes, 24(1), 339-344. https://doi.org/ $10.1590 / \mathrm{S} 0101-31222002000100046$

Kamala-Kannan, S., Han, S., Lee, K., Velmurugan, P., Lee, Y. H., Chae, J., \& Oh, B. (2011). Association of elm yellows subgroup 16SrV-B phytoplasma with a disease of Hovenia dulcis. Journal of Phytopathology, 159, 171-174. https://doi.org/10.1111/j.1439-0434.2010.01746.x

Kim, S., \& Han, J. (2008). Breeding of Korean raisin tree (Hovenia dulcis var. koreana Nakai) for high productivity in Korea. The Korean Journal of Breeding Science, 40(4), 371-376. Retrieved from http://db.koreascholar.com/article.aspx?code=307939

Labouriau, L. G. A. (1983). Germinação de sementes. Washington, DC: OEA.

Lima, C. R., Bruno, R. L. A., Silva, K. R. G., Pacheco, M. V., Alves, E. U., \& Andrade, A. P. (2012). Physiological maturity of fruits and seeds of Poincianella pyramidalis (Tul.) L. P. Queiroz. Revista Brasileira de Sementes, 34(2), 231-240. https://doi.org/10.1590/2317-1545v38n2154590

Lorenzi, H., Souza, H. M., Torres, M. A. V., \& Bacher, L. B. (2003). Árvores exóticas no Brasil: Madeireiras, ornamentais e aromáticas (1st ed.). Nova Odessa, SP: Plantarum.

Maguire, J. D. (1962). Speed of germination aid in selection and evaluation for seeding emergence and vigor. Crop Science, 2(2), 176-177. https://doi.org/10.2135/cropsci1962.0011183X000200020033x

Marcos-Filho, J. (2015). Fisiologia de sementes de plantas cultivadas (2nd ed.). Londrina, PR: Abrates.

Martins, C. C., Martinelli-Seneme, A., \& Nakagawa, J. (2008). Estágio de colheita e substrato para o teste de germinação de sementes de ipê (Tabebuia chrysotricha (Mart. ex DC.) Standl.) Revista Árvore, 32(1), 27-32. https://doi.org/10.1590/S0100-67622008000100004

Ministério da Agricultura Pecuária e Abastecimento. (2009). Regras para análise de sementes. Brasília, DF: Ministério da Agricultura Pecuária e Abastecimento.

Moraes, C. E., Lopes, J. C., Farias, C. C. M., \& Maciel, K. S. (2016). Qualidade fisiológica de sementes de Tabernaemontana fuchsiaefolia A. DC em função do teste de envelhecimento acelerado. Ciência Florestal, 26(1), 213-223. https://doi.org/10.5902/1980509821114

Munsell, A. H. (1976). Munsell book of color. Baltimore: Macbeth Vivision of Kollmorgen.

Oro, P., Schulz, D. G., Volkweis, C. R., Bandeira, K. B., Malavasi, U. C., \& Malavasi, M. M. (2012). Maturação fisiológica de sementes de Eugenia pyriformis Cambess e Eugenia involucrata DC. Biotemas, 25(3), 11-18. https://doi.org/10.5007/2175-7925.2012v25n3p11

Pereira, G. P., Carvalho, R. I. N., \& Biasi, L. A. (2010). Qualidade fisiológica de sementes de uva-do-japão após envelhecimento acelerado e armazenamento. Acta Scientiarum Agronomy, 32(3), 527-532. https://doi.org/ 10.4025/actasciagron.v32i3.4491

Pessoa, A. M. S., Mann, R. S., Santos, A. G., \& Ribeiro, M. L. F. (2012). Influência da maturação de frutos na germinação, vigor e teor de óleo de sementes de pinhão-manso (Jatropha curcas L.). Scientia plena, 8 (7), 1-11. Retrieved from https://www.scientiaplena.org.br/sp/article/view/407/554

Pimentel, A., Putton, V., Watzlawick, L. F., Valério, A. F., \& Saueressig, D. (2008). Fitossociologia do sub-bosque do Parque Ambiental Rubens Dallegrave. Revista Floresta, 38(3), 479-486. https://doi.org/ 10.5380/rf.v38i3.12413

Piña-Rodrigues, F. C. M., Figliolia, M. B., \& Peixoto, M. C. (2004). Teste de qualidade. In A. G. Ferreira, \& F. Borguetti (Eds.), Germinação: do básico ao aplicado (pp. 283-297). Porto Alegre, RS: Artmed.

Pontes, C. A., Corte, V. B., Borges, E. E. L., Silva, A. G., \& Borges, R. C. G. (2006). Influência da temperatura de armazenamento na qualidade das sementes de Caesalpinia peltophoroides Benth. (Sibipiruna). Revista Árvore, 30(1), 43-48. https://doi.org/10.1590/S0100-67622006000100006

Popinigis, F. (1985). Fisiologia da semente (2nd ed.). Brasília, DF: ABRATES.

Rodo, A. B., Perleberg, C. S., Torres, S. B., Gentil, D. F. O., \& Tessaroli Neto, J. (2001). Qualidade fisiológica e tamanho de sementes de cenoura. Scientia Agricola, 58(1), 201-204. https://doi.org/10.1590/S0103-847 82010000900008

Rosa, S. F., Longhi, S. J., \& Ludwig, M. P. (2008). Aspectos florísticos e fitossociológicos da Reserva Capão Tupanciretã, Tupanciretã, RS, Brasil. Ciência Florestal, 18(1), 15-25. https://doi.org/10.5902/19805098507 
Schumacher, M. V., Brun, E. J., Illana, V. B., Dissiuta, S. I., \& Agne, T. L. (2008). Biomassa e nutrientes em um povoamento de Hovenia dulcis Thun. plantado na Fepagro Florestas. Ciência Florestal, 18(1), 27-37. https://doi.org/10.5902/19805098519

Zanon, A., \& Carpanezzi, A. A. (1993). Influências da dormência tegumentar e do grau de maturação sobre a germinação de sementes de Hovenia dulcis T. Congresso Florestal Pan-Americano, 1, 294-297.

Zenni, R. D., \& Ziller, S. R. (2011). An overview of invasive plants in Brazil. Brazilian Journal of Botany, 34(3), 431-446. https://doi.org/10.1590/S0100-84042011000300016

\section{Copyrights}

Copyright for this article is retained by the author(s), with first publication rights granted to the journal.

This is an open-access article distributed under the terms and conditions of the Creative Commons Attribution license (http://creativecommons.org/licenses/by/4.0/). 